SUSAN PAYNE CARTER

\title{
Payday Loan and Pawnshop Usage: The Impact of Allowing Payday Loan Rollovers
}

\begin{abstract}
Millions of US households rely on payday loans and pawnshops for short-term credit. Payday loan interest rates are as high as $25 \%$ per 2- to 4-week loans and individuals use a post-dated check to secure the loan. Pawnshop usage is available for anyone with collateral. This article examines whether individuals using payday loans in states where rollovers are allowed are more likely to also use pawnshops together with payday loans. I find that this is true for individuals who make less than $\$ \mathbf{3 0 , 0 0 0}$, but it does not hold for those with higher levels of income. There may be some complementary relationships between payday loan rollovers and pawnshops for these lower-income individuals. These results are important when considering whether to allow payday loan rollovers.
\end{abstract}

"WARNING: A small loan is not intended to meet long term financial needs. A small loan should be used only to meet short term cash needs." Despite regulators forcing payday lenders to post this announcement, borrowers often do not heed the warning and extend their payday loans for months by paying the interest on the loan and prolonging repayment until the next period-a process called "rolling over." The practice of rolling over payday loans is popular, and 25 states have now prohibited rollovers on payday loans. ${ }^{2}$

1. Indiana state law, IN ST 24-4.5-7-101, Chapter 7 "Small Loans," requires this warning.

2. Over $50 \%$ of respondents in a national payday loan sample renewed payday loans three or more times (Lawrence and Elliehausen, 2008). The Consumer Financial Protection Bureau has a new paper documenting the frequency of individuals rolling over loans (Burke et al. 2014).

Susan Payne Carter (susan.carter@usma.edu) is an Assistant Professor, Department of Social Sciences, United States Military Academy, Office of Economic and Manpower Analysis. I would first of all like to thank the Vanderbilt Dissertation Fellowship for funding my final year of research at Vanderbilt. In addition, I would like to thank my dissertation committee William Collins, Andrew Daughety, Miguel Palacios, Paige Skiba, and Jennifer Reinganum for their helpful comments. I received numerous other helpful comments at seminars at various institutions while on the job market, and I am extremely grateful for all feedback. The views expressed in this article are those of the author and do not reflect the official policy or position of the Department of the Army, Department of Defense (DOD), or the US Government. All mistakes are my own.

The Journal of Consumer Affairs, Summer 2015: 436-456

DOI: 10.1111 joca. 12072

Copyright 2015 by The American Council on Consumer Interests 
Unlike credit from banks and payday lenders, pawnshop loans do not depend on credit scores and are available to anyone. As payday borrowers often have low credit scores and are credit constrained, pawnshops may be one of the only options low-income borrowers have available after exhausting payday loan options. ${ }^{3,4}$ This article looks at the use of payday loans and pawnshops together, and studies the relationship between state legislation allowing payday loan rollovers and their use. I find that borrowers who can roll over payday loans three or more times and have low levels of income are more likely to use pawnshops and payday loans together. Instead of the two forms of credit being substitutes, as we might expect, pawnshops may have a complementary relationship with rolling over loans for these individuals. For those with a slightly higher income (between $\$ 30,000$ and $\$ 50,000)$, however, additional rollovers are not associated with a greater use of payday loans and pawnshops together but are associated with a greater likelihood of using payday loans. This result would suggest that those using payday loans with slightly higher levels of income are not turning to pawnshops with additional levels of rollovers. These differing results depending on income status suggest that the relationship between payday and pawnshop use is heterogeneous across individuals and regulations focusing on limiting rollovers should consider how regulations may affect these populations differently.

Compared with traditional bank loans, credit unions, and credit card providers, both payday loans and pawnshops have high interest rates, with some charging up to $25 \%$ per loan (equivalent to an annual percentage rate (APR) of $650 \%$ if the interest was rolled over every two weeks $[25 \% \times 26 \%]$ ). If a borrower who is paid bi-weekly rolls over a $\$ 300$ payday loan at an interest rate of $15 \%$ for three months, the borrower pays $\$ 270$ in interest on that loan. On average, individuals in Skiba and Tobacman's (2008) sample of Texas payday borrowers who defaulted on their loans had already paid almost $90 \%$ of their loan in interest payments.

I use national-level survey data collected by the Federal Deposit Insurance Corporation (FDIC) as a supplement to the January 2009 Current Population Survey (CPS). The supplement asks questions on the use of

3. Logan and Weller (2009) find that one-third of payday borrowers have been denied credit during the past five years. Carter, Skiba and Tobacman (2011) show that payday borrowers are liquidity constrained relative to non-payday borrowers at a credit union in the western United States. Individuals at the credit union who did not take out payday loans had an average of $\$ 6,529$ available liquidity in their checking, savings, and line of credit accounts. Individuals who used a payday loan during a given six-month period only had an average of $\$ 832$ available. In addition, $70.1 \%$ of the payday borrowers in the sample had no available line of credit when they took out a payday loan.

4. Consumers also may turn to friends and family but there is minimal data on this form of credit. 
payday loans and pawnshops and provides an opportunity for researchers to study the use of multiple alternative financial services at a national level. As the survey is coupled with the detailed information provided in the CPS, I can control for demographic characteristics that may affect demand. According to the data, $3.4 \%$ of households in the United States use payday loans and $2 \%$ use pawnshops. ${ }^{5}$ Conditional on using a payday loan, there is a $13.8 \%$ chance an individual uses a pawnshop loan.

To my knowledge, this article is the first to study the relationship between renewal laws on the use of pawnshops together with payday loans. Understanding the services people use together and independently is important for giving a better understanding of the financial picture of individuals. Studies focusing on the reasons for using a particular service are important for determining the impacts of various regulations; however, the external impacts are important as well. For example, if payday loans are prohibited where else are borrowers turning? If borrowers are less constrained in terms of taking out payday loans (allowing more rollovers), does it have a positive or negative impact on substitutes? It remains to be studied empirically whether rolling over loans has a positive or negative effect on utility in general, but this article studies the first order impact of rollovers on the use of the two services.

\section{BACKGROUND ON PAYDAY LOANS AND PAWNSHOPS}

To secure a pawnshop loan, a borrower leaves a material possession at the pawnshop in exchange for cash. If the loan is not repaid, the object is forfeited. Borrowers need neither a bank account nor a job to secure one of these loans. ${ }^{6}$ Pawnshops are regulated at the state (and sometimes local) level, with limits on the length of the loan, the amount that can be charged for interest, and shop locations.

Meanwhile, to obtain a payday loan, a borrower writes a post-dated check in the amount of the loan plus interest due on the borrower's next payday. On the next payday, a borrower may choose to repay the loan, renew the loan by paying the interest again, or default. While most states do not allow payday loans to be renewed, 13 states allow up to six renewals or do not regulate renewals at all. Research on whether payday loans are

5. In 2007, the Survey of Consumer Finance began asking about the use of payday loans. A total of $2.38 \%$ of households had used them in the past year.

6. Johnson and Johnson (1998), however, report in their survey that $47.4 \%$ of their sample of active pawnshop borrowers had a checking account and $49.1 \%$ had a savings account. Only $36.4 \%$ had neither a checking nor a savings account. 
harmful or beneficial to borrowers is mixed and, at present, no definitive conclusion has been reached. ${ }^{7}$

There is surprisingly little economic research on pawnshops, despite having acted as an important source of credit for low-income borrowers for centuries. One exception is John Caskey's book Fringe Banking: Check-Cashing Outlets, Pawnshops, and the Poor, published in 1994, bringing attention to the understudied markets of pawnshops. The exact time and place where pawnshops began is uncertain, but there are biblical references to them in the Old Testament (Caskey 1994 from Levine 1991). The symbol of pawnshops (three gold circles) that continues to hang on most pawnshop storefronts today has its roots in the coat of arms of the Lombards, who first began pawning items in Britain (Caskey 1994). In the United States, pawnbroking began in the 17th century. By the 19th century, there were a number of philanthropic pawnshops. Pawnshop popularity diminished in the early 2000s; however, recent industry reports have revealed that the pawnshop demand has increased since the latest economic crisis (Haspel 2011). Today there are approximately 12,000 publicly and privately held pawnshops across the United States. ${ }^{8}$

Payday loans began to gain popularity in the mid 1990s and into the early 2000s. Caskey (2005) argues that the rise in payday lending helped lead to a decline of pawnshops. Many individuals who visited pawnshops had bank accounts and jobs, and therefore were eligible for payday loans. In addition, large pawnshops began to offer payday loans as well (Caskey 2005). By 2009, more than 10 million households used payday loans (Skiba and Tobacman 2011). More recently, payday loans have spread to traditional banks as well. Some banks, including US Bancorp, Regions, and Fifth Third Bank, have begun to offer direct-deposit advances that are similar to payday loans (Allyn 2011; Randall and Zibel 2011).

To study the policy implications of changing the number of rollovers allowed, Li, Mumford, and Tobias (2012) use online payday loan data to simulate the effect of changing state laws from allowing unlimited rollovers to allowing no rollovers. They estimate that this change would have no impact on the size of the loan taken out and would slightly decrease the probability of default.

7. When payday loans are eliminated, the number of bounced checks increases and Chapter 7 bankruptcy filings rise (Morgan and Strain 2008; Zinman 2010). In addition, with the availability of payday loans, individuals are better able to cope with income shocks caused by natural disasters (Morse 2011). On the other hand, it has also been shown that access to payday loans may increase financial hardships, especially difficulty paying bills, the need to postpone medical care (Melzer 2011), and filing for Chapter 13 bankruptcy (Skiba and Tobacman 2011).

8. http://www.uspawnshopdirectory.com/maillist.php. 
Avery and Samolyk (2011) use the FDIC supplement used in this article to study both payday and pawnshop loans. They look at the use of payday loans and pawnshops and measure the relationship between interest rate ceilings and the use of these two forms of credit as well as the number of storefronts. Their results do not show a large effect of interest ceilings on the use of payday loans; meanwhile, there is a positive relationship between the number of stores in operation and interest ceilings. These results suggest that lowering interest rates will cause payday lenders to adjust their operations, but it will allow borrowers to continue to take out loans at a lower cost.

\section{DATA}

I use national survey data to explore whether state variation in payday loan laws relates to the use of payday loans and pawnshops. In January of 2009, the FDIC added a questionnaire to the CPS to gain more information on the populations of individuals that do not have bank accounts and that use non-bank financial services. The survey asked questions on whether individuals had a bank account. ${ }^{9}$ In addition, it asked specific questions on the use of alternative financial services: payday loans, check cashing, pawnshops, rent-to-own usage, tax-refund anticipation loans, and non-bank money orders. For each of these services, the survey asked about the frequency of use and the reasons for using the service. These data give us a better understanding of what combinations of services people are using.

For someone to be considered a pawnshop user in my analysis, they must answer "yes" to the question "Have you or anyone in your household ever sold items at a pawn shop?" and have a frequency of use of either "At least a few times a year" or "Once or twice a year." Meanwhile, an individual is coded as using payday loans if they answer "yes" to the question "Have you or anyone in your household ever used payday loan or payday advance services?" and they say that they have taken out at least one payday loan in the past 12 months.

Summary statistics are included in Table 1 . Those who use either payday loans or pawnshops are younger and more likely to be married, to be a minority, to have no more than a high school degree, to not own a

9. Approximately $7.7 \%$ of households were without bank accounts, and another $17.9 \%$ had bank accounts but also used alternative forms of finance (FDIC 2009). A full summary of the findings as well as state averages can be found in the "Executive Summary" (FDIC 2009) and the "Addendum" (FDIC 2010). 
TABLE 1

Summary Statistics

\begin{tabular}{|c|c|c|c|c|}
\hline & $\begin{array}{c}\text { Use Neither } \\
\text { Payday Loans } \\
\text { Nor Pawnshops }\end{array}$ & $\begin{array}{c}\text { Use Just } \\
\text { Payday } \\
\text { Loans }\end{array}$ & $\begin{array}{c}\text { Use Just } \\
\text { Pawnshops }\end{array}$ & $\begin{array}{c}\text { Use Both Payday } \\
\text { Loans and } \\
\text { Pawnshops }\end{array}$ \\
\hline Age & $47.47(17.51)$ & $40.19(14.62)$ & $38.72(14.18)$ & $37.73(13.47)$ \\
\hline Female & $47.63 \%(0.50)$ & $46.69 \%(0.50)$ & $51.84 \%(0.50)$ & $46.13 \%(0.50)$ \\
\hline Married & $58.29 \%(0.49)$ & $44.54 \%(0.50)$ & $40.28 \%(0.49)$ & $42.64 \%(0.50)$ \\
\hline White & $85.01 \%(0.36)$ & $72.43 \%(0.45)$ & $75.22 \%(0.43)$ & $73.32 \%(0.44)$ \\
\hline Black & $8.50 \%(0.28)$ & $20.99 \%(0.41)$ & $16.73 \%(0.37)$ & $19.20 \%(0.39)$ \\
\hline Hispanic & $9.96 \%(0.30)$ & $11.82 \%(0.32)$ & $14.80 \%(0.36)$ & $13.97 \%(0.35)$ \\
\hline High school grad & $30.60 \%(0.46)$ & $37.47 \%(0.48)$ & $38.44 \%(0.49)$ & $39.65 \%(0.49)$ \\
\hline Some college & $28.09 \%(0.45)$ & $34.91 \%(0.48)$ & $27.23 \%(0.45)$ & $33.17 \%(0.47)$ \\
\hline College plus & $29.30 \%(0.46)$ & $12.53 \%(0.33)$ & $11.65 \%(0.32)$ & $7.23 \%(0.26)$ \\
\hline Not a citizen & $6.61 \%(0.25)$ & $5.37 \%(0.23)$ & $6.39 \%(0.24)$ & $3.49 \%(0.18)$ \\
\hline One child & $11.63 \%(0.32)$ & $14.86 \%(0.36)$ & $13.92 \%(0.35)$ & $17.20 \%(0.38)$ \\
\hline More than one child & $16.55 \%(0.37)$ & $22.38 \%(0.42)$ & $20.67 \%(0.41)$ & $26.43 \%(0.44)$ \\
\hline Unbanked & $5.13 \%(0.22)$ & $9.31 \%(0.29)$ & $27.15 \%(0.44)$ & $23.94 \%(0.43)$ \\
\hline Employed & $51.44 \%(0.50)$ & $49.51 \%(0.50)$ & $40.72 \%(0.49)$ & $41.90 \%(0.49)$ \\
\hline Own a home & $74.90 \%(0.43)$ & $46.24 \%(0.50)$ & $43.70 \%(0.50)$ & $43.96 \%(0.50)$ \\
\hline \multicolumn{5}{|l|}{ Income ranges } \\
\hline Income $<\$ 30,000$ & $25.89 \%$ & $35.77 \%$ & $57.43 \%$ & $47.95 \%$ \\
\hline $\begin{array}{l}\text { Income between } \\
\$ 30,000 \text { and } \$ 50,000\end{array}$ & $20.83 \%$ & $28.73 \%$ & $21.54 \%$ & $29.53 \%$ \\
\hline $\begin{array}{l}\text { Income greater than } \\
\$ 50,000\end{array}$ & $53.28 \%$ & $35.50 \%$ & $21.03 \%$ & $22.52 \%$ \\
\hline
\end{tabular}

Note: Table 1 reports summary statistics on individuals who have not reported using payday loans or pawnshops in the past year, have used just payday loans, have used just pawnshops, or have used both. Only states where payday loans are legal are included.

home, and to have children relative to those that use neither service. When comparing those who use just payday loans, just pawnshops, and those that use both, it is not surprising that individuals who use just pawnshops are more likely to not have a bank account (be unbanked) than those using just payday loans. To take out a payday loan, individuals need to have a bank account, so individuals who report using payday loans may have used them in the past year and then no longer have a bank account. Those using just pawnshops are also more likely to be female. Relative to those who use just payday loans or just pawnshops, those that use both services are more likely to have children. Individuals using these two services are also more likely to have lower incomes. For example, $35.77 \%$ of people just using payday loans make less than $\$ 30,000,57.43 \%$ of people using just pawnshops make less than $\$ 30,000$, and $47.95 \%$ of those that use both make less than $\$ 30,000$. 


\section{ESTIMATION STRATEGY}

As presented in Table 2, the state rules on payday loans and pawnshops vary. I am interested in the use of payday loans and pawnshop loans, focusing on the number of renewals allowed and controlling for interest rates. State regulations on the number of rollovers vary from allowing zero to not specifying a limit. Geographically, states that allow rollovers are scattered across the United States, as are states that prohibit rollovers. Figure 1 presents a map of the contiguous United States indicating states where payday loans are illegal, and for states where rollovers are legal, the number of rollovers allowed in each state. As the table and figure indicate, a number of states prohibit payday loans, and I remove these states from my analysis.

Ideally, to test for a causal effect of rollovers, those living in states with and without payday loans would be the same except for this difference in the law. Table 3 reports summary statistics on individuals living in states that do and do not allow rollovers. Those in states that do not allow rollovers have a slightly higher minority rate and slightly less education on average. They also have more people $(6.51 \%$ relative to $5.31 \%)$ who are unbanked and slightly fewer (50.38\% vs. $52.62 \%)$ people employed. Otherwise individuals in the two groups of states appear similar. I further split the states that allow rollovers into those states that allow one or two rollovers vs. those who allow three or more rollovers. Again, the summary statistics do not reveal significant differences between these groups in terms of the population. Despite this, in my analysis, I cannot make a causal argument that payday loan rollovers cause any differences in payday and pawnshop rate because there may be unobservable characteristics about people living in these various states, which lead them to be more or less likely to use these services.

I measure the factors that affect an individual's decision to use payday loans and pawnshops by employing a multinomial logit model and using variation in state laws. The multinomial logit is an extension of the binary logit model which enables a test of the probability of unordered responses. The four cases in this multinomial logit are: (1) neither payday loans nor pawnshops are used, (2) only payday loans are used, (3) only pawnshops are used, and (4) payday loans and pawnshops are both used. I restrict the sample to only those states where payday loans are legal. In addition, I run separate ordinary least square (OLS) regressions to measure whether rollover laws are associated with use of each service in general as well. While the multinomial results may show that individuals are more or less likely to use both services together and more or less likely to only use 


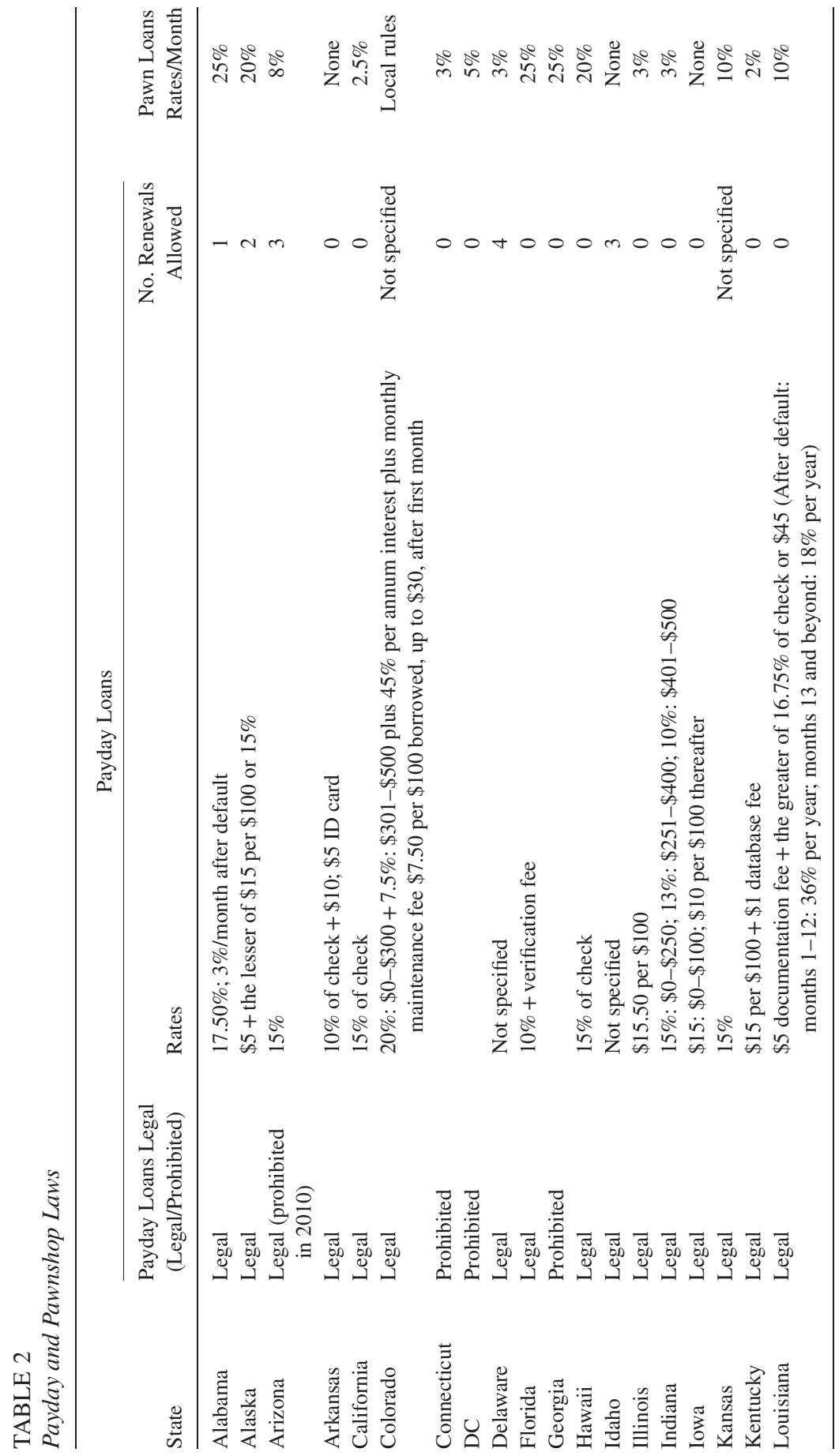




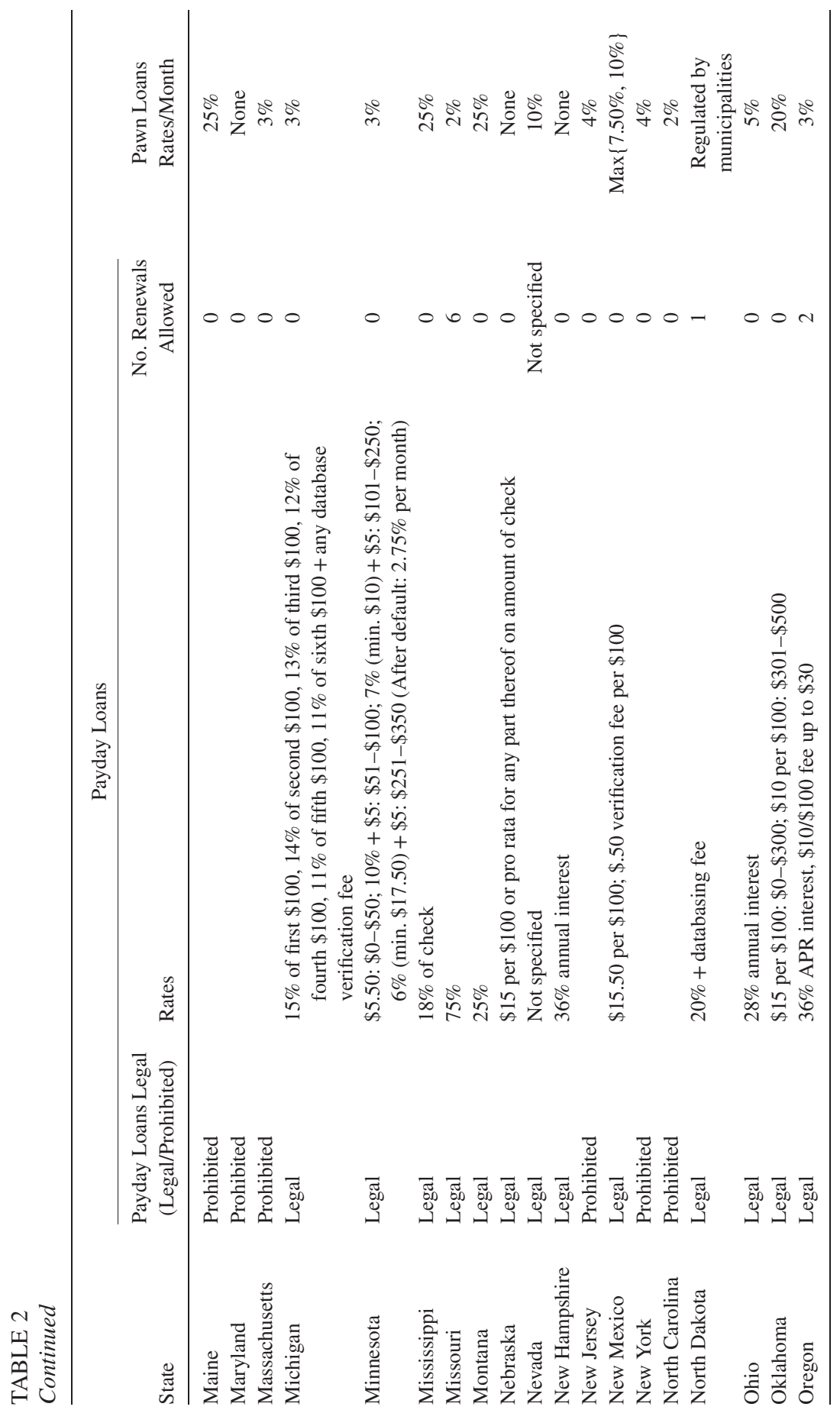




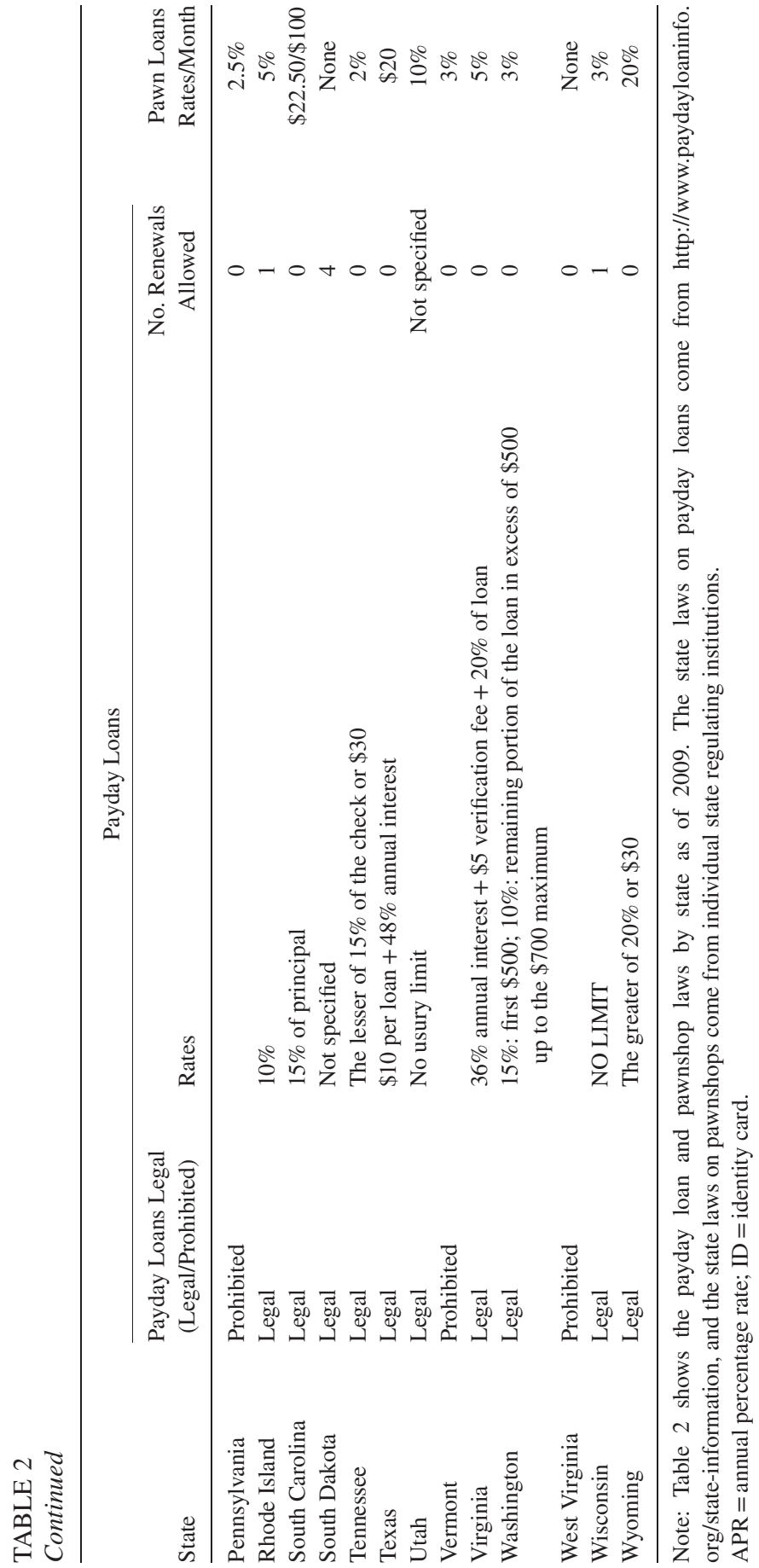


FIGURE 1

Payday Loan Legality and Number of Rollovers Allowed

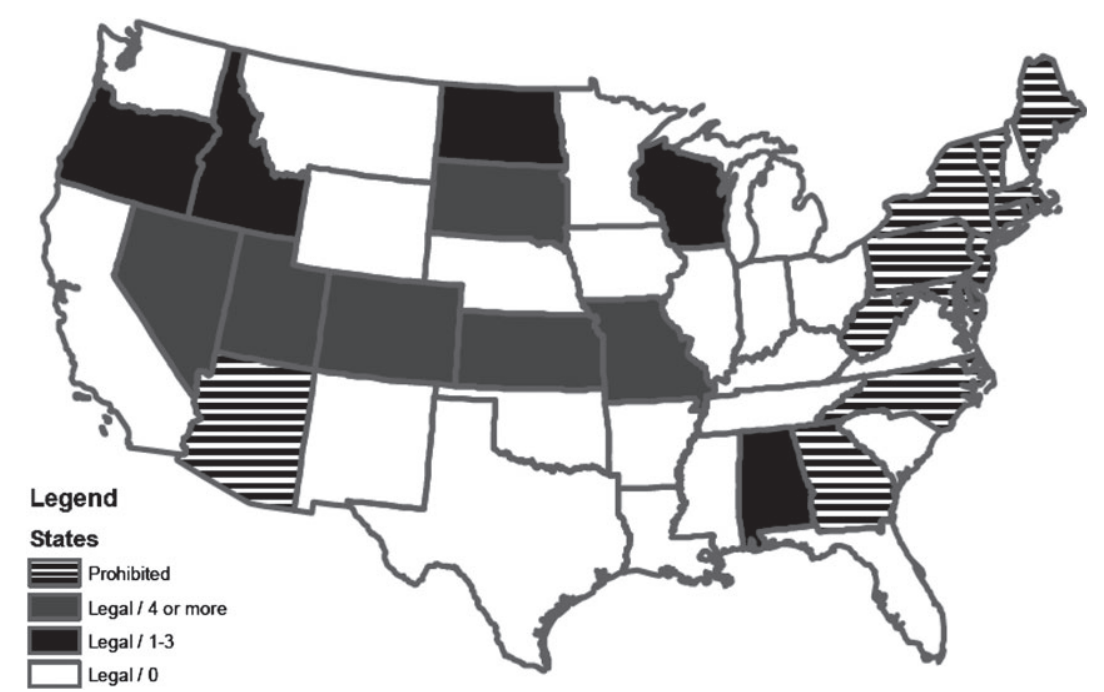

Note: Payday loans became illegal in 2010 in Arizona. Rhode Island allows payday loans but prohibits rollovers. Delaware allows up to four rollovers.

payday loans or only use pawnshop loans, it might hide whether they are generally more or less likely to use each one of the services. For example, if the results showed that individuals were more likely to use payday loans and pawnshop loans together, it may be a result of more people using payday loans, irrespective of whether they use pawnshop loans. By looking at the OLS results in addition to the multinomial logit results, it will show whether this is driving the results.

To capture observed factors that would affect the use of both payday loans and pawnshops, I control for a number of demographic characteristics including sex, age, marital status, the presence of children, and education. I also include a dummy for whether someone has been on active duty in the military. ${ }^{10}$ I include controls for state effects that may affect use, specifically payday and pawnshop interest rate regulations, and I cluster the standard errors at the state level. In addition, I control for income and then further condition my samples based on income. While some individuals with earnings more than $\$ 100,000$ per year do report payday loan 
TABLE 3

Summary Statistics across States

\begin{tabular}{|c|c|c|c|c|}
\hline & $\begin{array}{l}\text { No Rollovers } \\
\text { Allowed }\end{array}$ & $\begin{array}{l}\text { Rollovers } \\
\text { Allowed }\end{array}$ & $\begin{array}{c}\text { Rollovers } \\
\text { Allowed but } \\
\text { Capped at } 2 \\
\text { or Less }\end{array}$ & $\begin{array}{l}\text { Three or } \\
\text { More } \\
\text { Rollovers } \\
\text { Allowed }\end{array}$ \\
\hline Age & $46.82(17.44)$ & $46.72(17.45)$ & $47.13(17.41)$ & $46.45(17.46)$ \\
\hline Female & $47.74 \%(0.50)$ & $48.29 \%(0.50)$ & $48.34 \%(0.50)$ & $48.25 \%(0.50)$ \\
\hline Married & $57.84 \%(0.49)$ & $58.58 \%(0.49)$ & $57.84 \%(0.49)$ & $59.06 \%(0.49)$ \\
\hline White & $83.31 \%(0.37)$ & $88.16 \%(0.32)$ & $87.30 \%(0.33)$ & $88.71 \%(0.32)$ \\
\hline Black & $8.89 \%(0.28)$ & $5.74 \%(0.23)$ & $5.91 \%(0.24)$ & $5.63 \%(0.23)$ \\
\hline Hispanic & $13.03 \%(0.34)$ & $7.86 \%(0.27)$ & $4.57 \%(0.21)$ & $10.00 \%(0.30)$ \\
\hline High school grad & $30.90 \%(0.46)$ & $31.06 \%(0.46)$ & $31.52 \%(0.46)$ & $30.76 \%(0.46)$ \\
\hline Some college & $28.91 \%(0.45)$ & $30.84 \%(0.46)$ & $30.75 \%(0.46)$ & $30.90 \%(0.46)$ \\
\hline College plus & $26.80 \%(0.44)$ & $26.98 \%(0.44)$ & $27.02 \%(0.44)$ & $26.96 \%(0.44)$ \\
\hline Not a citizen & $7.46 \%(0.26)$ & $5.20 \%(0.22)$ & $4.05 \%(0.20)$ & $5.94 \%(0.24)$ \\
\hline One child & $12.06 \%(0.33)$ & $11.57 \%(0.32)$ & $11.41 \%(0.32)$ & $11.67 \%(0.32)$ \\
\hline More than one child & $16.95 \%(0.38)$ & $17.53 \%(0.38)$ & $16.27 \%(0.37)$ & $18.36 \%(0.39)$ \\
\hline Unbanked & $6.51 \%(0.25)$ & $5.31 \%(0.22)$ & $4.85 \%(0.21)$ & $5.61 \%(0.23)$ \\
\hline Employed & $50.38 \%(0.50)$ & $52.62 \%(0.50)$ & $52.87 \%(0.50)$ & $52.46 \%(0.50)$ \\
\hline Own a home & $72.98 \%(0.44)$ & $73.88 \%(0.44)$ & $72.99 \%(0.44)$ & $74.46 \%(0.44)$ \\
\hline \multicolumn{5}{|l|}{ Income ranges } \\
\hline Income $<\$ 30,000$ & $27.47 \%(0.45)$ & $26.61 \%(0.44)$ & $27.09 \%(0.44)$ & $26.30 \%(0.44)$ \\
\hline $\begin{array}{l}\text { Income between } \$ 30,000 \\
\text { and } \$ 50,000\end{array}$ & $21.16 \%(0.41)$ & $21.67 \%(0.41)$ & $19.62 \%(0.40)$ & $22.98 \%(0.42)$ \\
\hline $\begin{array}{l}\text { Income between } \$ 50,000 \\
\text { and } \$ 100,000\end{array}$ & $32.68 \%(0.47)$ & $33.54 \%(0.47)$ & $34.60 \%(0.48)$ & $32.87 \%(0.47)$ \\
\hline Income $>\$ 100,000$ & $18.70 \%(0.39)$ & $18.18 \%(0.39)$ & $18.69 \%(0.39)$ & $17.85 \%(0.38)$ \\
\hline
\end{tabular}

Note: Table 3 reports summary statistics on individuals who live in states that do and do not allow individuals to roll over payday loans. Only states where payday loans are legal are included.

and pawnshop use, the majority of individuals using these services earn less. After running the full sample, I then condition on those individuals who make less than $\$ 30,000$ and those who make between $\$ 30,000$ and $\$ 50,000$. For the full population of individuals in states that allow payday loans, $0.6 \%$ of people report using both of them, $4 \%$ report using payday loans, and $2.2 \%$ report using pawnshops. When conditioning on those people who make less than $\$ 30,000$ per year, $1.2 \%$ report using both payday loans and pawnshops, 5.7\% report using payday loans, and $4.5 \%$ report using pawnshops. For those who make between $\$ 30,000$ and $\$ 50,000,0.9 \%$ report using both, $5.6 \%$ report using payday loans, and $2.6 \%$ report using pawnshops.

My main variable of interest is the number of rollovers allowed. If a state does not place a limit on the number of rollovers allowed, I define the number of rollovers allowed to be six, which is the maximum of any 
other state. After running the initial regression, I then split the sample into those states with two or fewer rollovers allowed and those with three or more rollovers allowed, including those states that do not place a limit on the number of rollovers. The relationship between the number of rollovers and use of these two alternative financial services may not be linear, and splitting the number in few and many rollovers allows for this flexibility.

\section{RESULTS}

The results for the multinomial logit are reported in Table 4. The first panel (Panel A) includes relative risk ratios for the number of rollovers. The second panel (Panel B) includes relative risk ratios for three or more rollovers or two or fewer rollovers, relative to states where no rollovers are allowed.

Those living in states with more rollovers have a relative risk ratio of 1.09 that is statistically significant. This suggests that the more rollovers allowed is associated with an increase in the use of both payday loans and pawnshops. Individuals are also slightly more likely to use just payday loans and slightly less likely to use just pawnshops.

As mentioned in the previous section, this result can be explained by either more rollovers being associated with more people using both payday loans and pawnshops or just more people using payday loans in general, with the same use of pawnshops. To study that question, I turn to OLS regressions looking at the use of payday loans and pawnshops, reported in Table 5. The OLS results paint a similar story. More rollovers are associated with an increased likelihood that individuals use both payday loans and pawnshops but by only 0.05 percentage points on a control mean of 0.65 percentage points and an increase in their use of payday loans in general of 0.3 percentage points on a control mean of 4 percentage points.

I then split the states into those that allow few and those that allow many rollovers. For those individuals living in states with three or more rollovers relative to states where payday loans are legal but no rollovers are allowed, the relative risk ratio is 1.74 for using both payday loans and pawnshops, suggesting an increase in the use of joint use of payday loans and pawnshops. The relative risk ratio of using just payday loans is 1.70 , suggesting that additional rollovers increase the likelihood that individuals will use just payday loans. The relative risk ratio for using just pawnshops is 0.57 , suggesting fewer people only turning to pawnshops. In states where only one or two rollovers are allowed, the relative risk ratios for any of the outcomes are statistically insignificant. 


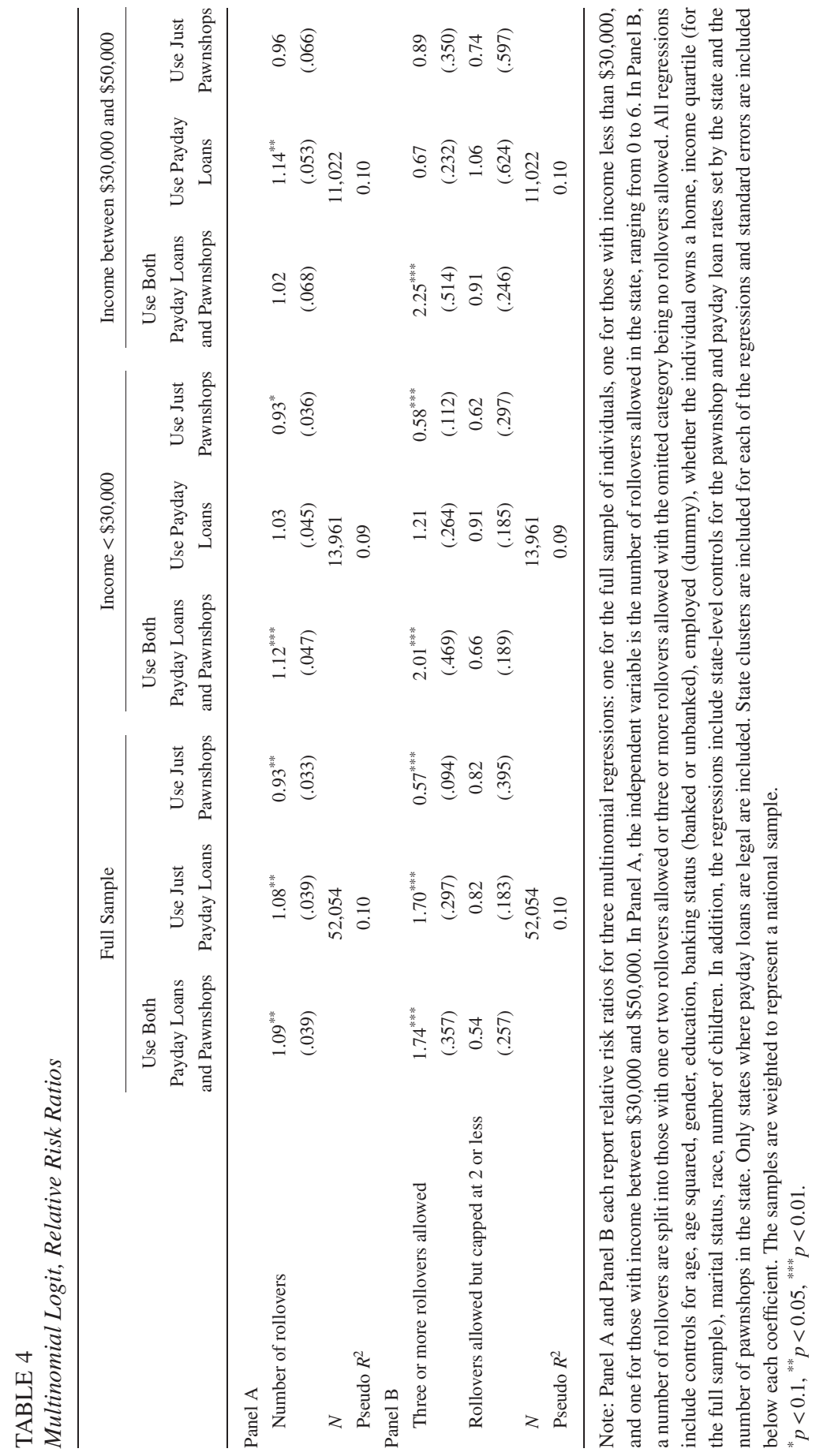




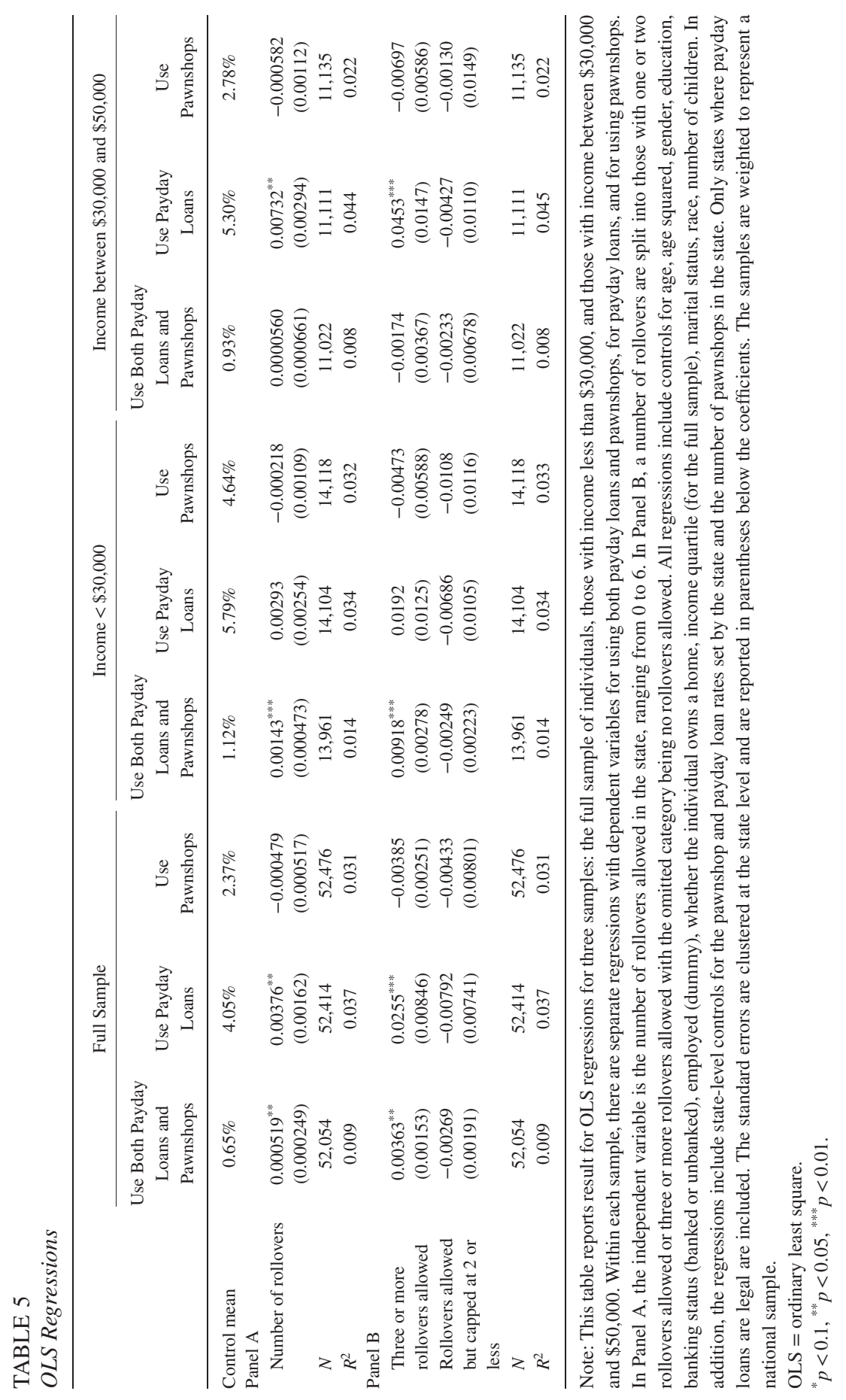


The results for separate OLS regressions are shown in Panel B of Table 5. Individuals in states with a higher number of rollovers are more likely to use payday loans and pawnshops together by 0.3 percentage points and an increase likelihood of using payday loans by 2.55 percentage points. There is no statistically significant effect on the use of pawnshop loans. Together, this suggests that a higher number of rollovers are related to a greater use of payday loans but no change in pawnshop usage, so it is not clear if rollovers are more likely to be used together with pawnshops or not.

\section{Heterogeneous Effects by Income}

While the previous results suggested that payday loan rollovers and pawnshops are not necessarily complements or substitutes, the impact of rolling over loans may be different for individuals based on their income. Those with lower levels of income may not have the ability to repay the renewal rate each month, and thus have to turn to pawnshops more often. I split the sample into those with less than $\$ 30,000$ income and those with an income between $\$ 30,000$ and $\$ 50,000$. I again run the same regressions as previously reported and the results are in Tables 4 and 5 .

First, I turn to the results looking at the association between the number of rollovers and the use of both payday loans and pawnshops. The results are similar to before with more rollovers slightly increasing the use of both, slightly increasing the use of just payday loans, and slightly decreasing the use of pawnshops. When I turn to the OLS results, however, for those with income less than $\$ 30,000$, more rollovers are associated with an increased use of both payday loans and pawnshops by 0.14 percentage points on a control mean of $1.1 \%$, which is just over a $10 \%$ effect. Meanwhile, there is no effect on either of the services in general. For those with income between $\$ 30,000$ and $\$ 50,000$, there is an increased use of payday loans but no subsequent increase in the use of both services together. These results suggest that for lower-income individuals there may be some complementary relationship between rollovers and payday loans but not for low- to mid-income individuals.

I then turn to the results when splitting up the number of rollovers into two or fewer and three or more rollovers. In the multinomial regressions for those with less than $\$ 30,000$ income, being in a state that allows three or more rollovers has a relative risk ratio of 2.01 for using both services. The relative risk ratio on using just payday loans is 1.21 and not statistically significant and on just pawnshop loans is 0.58 and is statistically significant at the $5 \%$ level. These results together suggest no significant impact on using just payday loans but an increased likelihood 
of using both payday loans and pawnshops. I then run the OLS regressions for this same subsample. The probability that an individual uses a payday loan is unchanged by the number of rollovers, and the probability that an individual uses a pawnshop loan is unchanged. However, the probability that an individual uses both payday loans and pawnshop loans increases by 0.92 percentage points on a control mean of $1.12 \%$. This result would again indicate that in states that allow many rollovers, there is a complementary relationship between payday loan rollovers and pawnshops for low-income individuals.

When studying those who have a higher income (between $\$ 30,000$ and $\$ 50,000)$, the results are similar to the full sample not conditioned on income with even greater effects on the likelihood of taking out payday loans. This result would suggest that there is little, if any, complementary relationship between pawnshops and payday loans when a high number of rollovers are allowed for individuals that make between $\$ 30,000$ and $\$ 50,000$.

I additionally split the sample based on race, gender, and education, as shown in Table 6. Females in states with three or more rollovers are more likely to use both services as well as more likely to use payday loans. There is no statistically significant effect on the use of pawnshops. Non-whites are also more likely to use both, more likely to use payday loans, and slightly less likely to use pawnshop loans. Those without any college education are slightly more likely to use payday loans when three or more rollovers are allowed. In none of these results does it appear that there is an increased use in both payday loans and pawnshops without there being an increased use of payday loans in general. This would suggest, then, that income is the driver for the complementary relationship between payday loans and pawnshops.

\section{DISCUSSION AND CONCLUSION}

Payday loans are an expensive form of credit used by millions of low-income people each year. State laws on payday loans vary in terms of the interest rate and the number of rollovers allowed (if any). Recent papers on payday loans have focused on the welfare costs or benefits of allowing access to short-term credit. This article instead focuses on states allowing rollovers on payday loans and the use of another form of nontraditional banking, pawnshop usage. The article is one of the few to look at the combined use of payday loans and pawnshops and the first to study the relationship with states allowing rollovers. Understanding the full portfolio of an individual's credit decisions is important when considering financial 


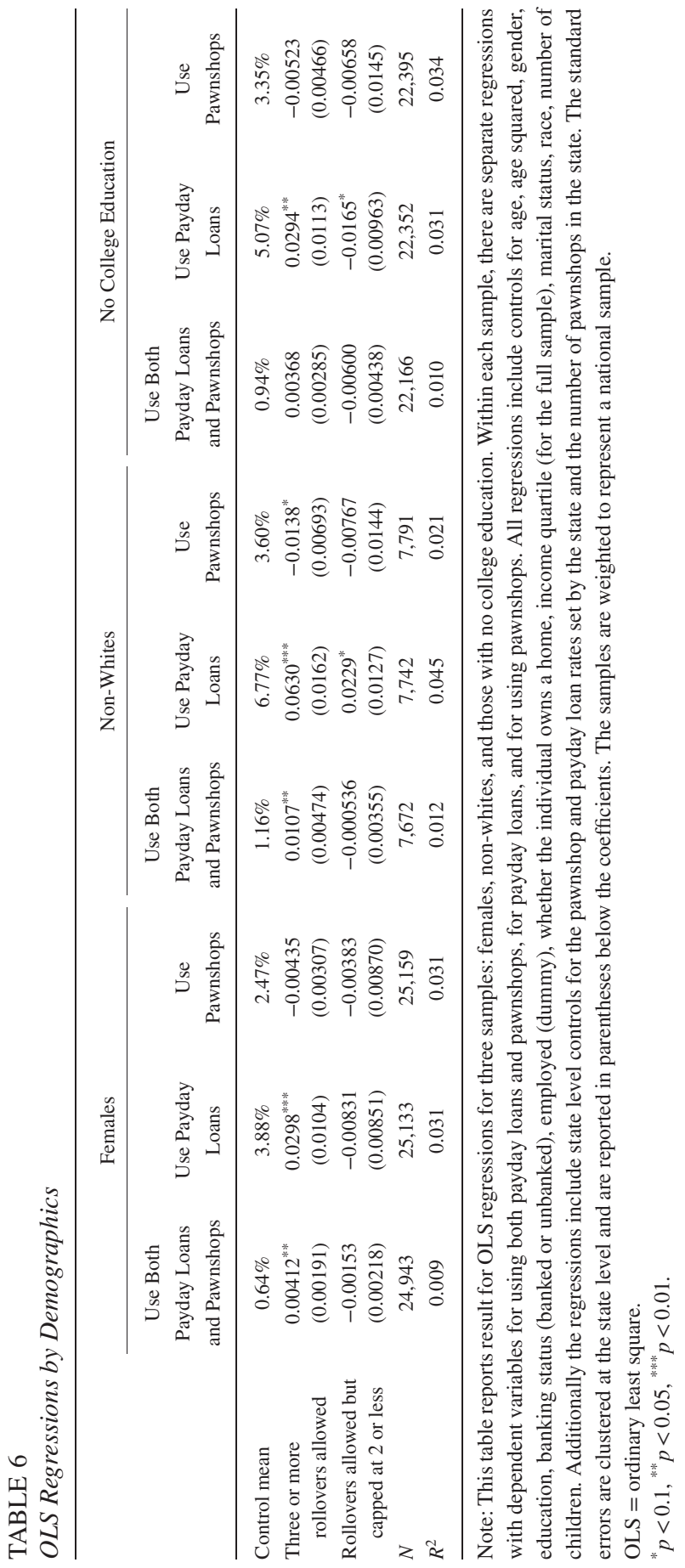


regulations. This article is just one step in establishing a relationship between two forms of alternative financial services.

Using data from a survey conducted by the FDIC, I find that individuals with low levels of income living in areas where three or more rollovers are permitted are more likely to use pawnshops and payday loans. Meanwhile, those with a higher income are more likely to use payday loans but there is no effect on pawnshop usage. There are a few reasons which could explain these results.

First of all, one of the limitations of the study is the use of cross-sectional data without random assignment, so a causal argument for the allowance of rollovers and use of pawnshops and payday loans cannot be made. We do not know whether individuals living in states that allow payday loan rollovers are generally individuals that are more inclined to use either or both of the services or whether state laws that impact rollover use also affect other factors that affect the use of both services. Ideally, there would be a change in a rollover law unassociated with other factors related to the use of the service, and one could test whether this effect changed the use of payday loans and pawnshops relative to other services. Or, if individuals were randomly assigned to states, I might be able to make a causal argument.

Second, one of the major complaints against payday loans is the belief that individuals get stuck in a debt cycle when they take out a loan. It could be, therefore, that payday loan rollovers lead low-income individuals into falling further into debt, and thus they need to take out pawnshop loans to supplement their income. If individuals do not have the funds to pay the rollover fee, then taking out a pawnshop loan may be their preferred method of payment. Alternatively, individuals may fall into so much debt as a result of payday loan rollovers and thus have to turn to pawnshops to help with consumption, either because they are repaying their loan and thus need to take on more debt or because they default on their payday loans and need to take out pawnshop loans. It, however, does not appear that those with slightly higher levels of income have to turn to pawnshops when more payday loan rollovers are allowed. It is possible that they are turning to other sources of credit to help pay off their payday loans.

Finally, individuals may not be using full information or being rational when using payday loans. Bertrand and Morse (2011) find that increased information disclosures to payday loans customers increased repayment rates and decreased indebtedness for some individuals. Carter, Skiba, and Sydnor (2012) find that additional time to repay a loan does not affect repayment rates, which is hard to explain using rational models of repayment. It may be that individuals using payday loans are exhibiting present 
biased behavior, such as hyperbolic discounting, or do not understand the impact of using payday loans. When given the chance to roll over a loan, low-income individuals may rather take out a pawnshop loan, or another payday loan, than repaying it immediately. Increased disclosure statements that show individuals the debt cycle they might fall into if they do not repay might help individuals both in the reduction of the use of payday loans and of pawnshops if they are not using full information when making their decisions. I cannot test this result in this article, but it might be a policy avenue that would help these individuals without prohibiting the loans.

The article shows that in states where payday loan rollovers are allowed there is no impact on the likelihood of using payday loans or pawnshops for low-income individuals but there is an increased likelihood that they will use both of them. These results suggest that there may be some negative consequences for low-income individuals when they are not bound by rollover limits. The welfare impacts of rolling over payday loans need to be examined further, but it is clear that regulations on payday loans, specifically rollovers, may affect individuals differently based on income.

\section{REFERENCES}

Allyn, Bobby. 2011. Banks Adopt Payday Loans. The Tennessean. August 25.

Avery, Robert B. and Katherine A. Samolyk. 2011. Payday Loans versus Pawn Shops: The Effects of Loan Fee Limits on Household Use. Working Paper. http://web.law.columbia.edu/sites/ default/files/microsites/transactional-studies/files/10PDL_averysamolykpayday.20110909_0.pdf

Bertrand, Marianne and Adair Morse. 2011. Information Disclosure, Cognitive Bias, and Payday Borrowing. Journal of Finance, 66 (6): 1865-1893.

Burke, Kathleen, Jonathan Lanning, Jesse Leary, and Jialan Wang. 2014. CFPB Data Point: Payday Lending. The CFPB Office of Research, March. http://files.consumerfinance.gov/f/201403_cfpb_ report_payday-lending.pdf

Carter, Susan Payne, Paige Marta Skiba, and Jeremy Tobacman. 2011. Pecuniary Mistakes? Payday Borrowing by Credit Union Members. In Financial Literacy: Implications for Retirement Security and the Financial Marketplace, edited by Olivia S. Mitchell and Annamaria Lusardi (145-157). Oxford, UK: Oxford University Press.

Carter, Susan Payne, Paige Marta Skiba, and Justin Sydnor (2012). The Difference a Day Makes: Measuring the Impact of Payday Loan Length on the Probability of Repayment. Work in Progress.

Caskey, John P. 1994. Fringe Banking: Check Cashing Outlets, Pawnshops, and the Poor. New York, NY: Russell Sage Foundation.

- 2005. Fringe Banking and the Rise of Payday Lending. In Credit Markets for the Poor, edited by Patrick Bolton and Howard Rosenthal (17-45). New York, NY: Russell Sage Foundation.

Federal Deposit Insurance Corporation, FDIC. 2009. FDIC National Survey of Unbanked and Underbanked Households: Executive Summary. December. https://www.fdic.gov/household survey/2009/executive_summary.pdf.

- 2010. Addendum to the 2009 FDIC National Survey of Unbanked and Underbanked Households: Use of Alternative Financial Services. September. https://www.fdic.gov/house holdsurvey/2009/AFS_Addendum.pdf.

Haspel, Savannah. 2011. Pawn Shops Market Research Report Now Available from IBISWorld. Yahoo News, September 22. http://news.yahoo.com/pawn-shops-market-research-report-nowavailable-ibisworld-072428050.html 
Johnson, Robert W. and Dixie P. Johnson. 1998. Pawnbroking in the US: A Profile of Customers. Washington, DC: The Credit Research Center, School of Business, Georgetown University.

Lawrence, Edward C. and Gregory Elliehausen. 2008. A Comparative Analysis of Payday Loan Customers. Contemporary Economic Policy, 26 (2): 299-316.

Li, Mingliang, Kevin J. Mumford, and Justin L. Tobias. 2012. A Bayesian Analysis of Payday Loans and Their Regulation. Journal of Econometrics, 171 (2): 205-216.

Logan, Amanda and Christian E. Weller. 2009. Who Borrows from Payday Lenders? An Analysis of Newly Available Data. Center for American Progress, March. https://cdn.americanprogress .org/wp-content/uploads/issues/2009/03/pdf/payday_lending.pdf

Melzer, Brian. 2011. The Real Costs of Credit Access: Evidence from the Payday Lending Market. Quarterly Journal of Economics, 126 (1): 517-555.

Military Payday Loans. 2009. Military Loan Resources. April 15. http://www.militaryloanresources .com/payday-loans/military-payday-loans.html

Morgan, Donald P. and Michael R. Strain. 2008. Payday Holiday: How Households Fare after Payday Credit Bans. Federal Reserve Bank of New York Staff Report No. 309, November. http://www.newyorkfed.org/research/staff_reports/sr309.html

Morse, Adair. 2011. Payday Lenders: Heroes or Villans. Journal of Financial Economics, 102 (1): 28-44.

Randall, Maya Jackson and Alan Zibel. 2011. Banks' Direct-Deposit Advances Spark Lending Debate. The Wall Street Journal, August 12. http://online.wsj.com/article/SB10001424053111904006104 576502793158420916.html.

Skiba, Paige Marta and Jeremy Tobacman. 2008. Payday Loans, Uncertainty, and Discounting: Explaining Patterns of Borrowing, Repayment, and Default. Vanderbilt Law and Economics Working Paper, No. 08-33. http://papers.ssrn.com/sol3/papers.cfm?abstract_id=1319751

- 2011. Do Payday Loans Cause Bankruptcy? Vanderbilt Law and Economics Working Paper, No. 11-13. http://papers.ssrn.com/sol3/papers.cfm?abstract_id=1266215

Zinman, Jonathan. 2010. Restricting Consumer Credit Access: Household Survey Evidence on Effects around the Oregon Cap Rate. Journal of Banking \& Finance, 34 (3): 546-556. 